www.periodicos.unimontes.br/index.php/caminhosdahistoria

\title{
'RAÍZES RACIAIS' DO PROJETO INTEGRALISTA (NACIONAL) DE GUSTAVO BARROSO: O PRECONCEITO, A INTOLERÂNCIA E O RACISMO PARA COM A FIGURA DO JUDEU NO BRASIL DA DÉCADA 1930
}

\section{Cícero João da Costa Filho ${ }^{1}$}

Resumo: Na década de 1930 o Brasil viveu uma tensa conjuntura política, no qual viu despontar o movimento integralista, que contou com a participação de Gustavo Barroso. Figura importante no campo político e literário brasileiro, barroso propôs um projeto de Brasil extremamente autoritário, autoritário e corporativo. Chefe de milícia dos camisas verdes, o projeto integralista do escritor combate seu imaginário sobre a figura do judeu, sujeito ganancioso, apátrida, de caráter revolucionário. O antissemitismo aberto de Barroso, diferente do de Plínio Salgado e Miguel Reale, é parte integrante de seu projeto nacional. O escritor buscou entender o Brasil entendendo que o judeu era o responsável pelos inúmeros problemas nacionais, sendo necessário sua eliminação. Simpático ao fascismo e ao nacional socialismo alemão, Barroso disseminou particularidades da política nazista, propondo a eliminação do judeu, visto suas características malévolas. O Brasil dos anos 1930, nos mais variados segmentos, estava para a eliminação do judeu, segundo Gustavo Barroso.

Palavras-chave: Gustavo Barroso, Judeu, Nazismo, Fascismo, Integralismo.

Abstract: In the 1930s, Brasil experienced a tense political situation, in which the integralista movement emerged, with the participation of Gustavo Barroso. An important figure in the Brazilian political and literary field, Barroso proposed a project from Brazil that was extremely authoritarian, authoritarian and corporate. Head of militia in the green shirts, the integralist project of the writer combats his imaginary about the figure of the Jew, a greedy, stateless subject of a revolutionary character. Barroso's open anti-Semitism, unlike that of Plínio Salgado and Miguel Reale, is an integral part of his national project. The writer sought to understand Brazil by understanding that the Jew was responsible for numerous national problems, requiring its elimination. Sympathetic to fascism and German national socialism, Barroso disseminated particularities of Nazi politics, proposing the elimination of the Jew, given his malevolent characteristics. The Brazil of the 1930s, in the most varied segments, was about to eliminate the Jew, according to Gustavo Barroso.

Keywords: Gustavo Barroso, Jew, Nazism, Fascism, Integralism.

Resumen: En la década de 1930 Brasil experimentó una situación política tensa, en la que vio surgir el movimiento fundamentalista, que contó con la participación de Gustavo Barroso. Figura importante en el campo político y literario de Brasil, Barroso Brasil propuso un proyecto extremadamente autoritario, autoritario y corporativo. Jefe de milicias de las camisas verdes, el proyecto escritor de combate fundamentalista su imaginación sobre la figura judía, sujetos codiciosos, sin estado, carácter revolucionario. El abierto antisemitismo Barroso,

\footnotetext{
${ }^{1}$ Doutorado e pós-doutorado pela Faculdade de Filosofia, Letras e Ciências Humanas da Universidade de São Paulo. Cursa o pós-doutorado com a pesquisa Do feixe à pena, um "fascista democrata": uma análise do Estado brasileiro na Obra Política de Miguel Reale (1931-1937), sob a supervisão da Prof. a Maria Aparecida de Aquino. E-mail de contato: cicerojoaofilho@gmail.com. ORCID: https://orcid.org/0000-0001-5246-8201.
} 
diferente de Plinio Salgado y Miguel Reale, es una parte integral de su proyecto nacional. El escritor trató de comprender Brasil entiende que el Judio fue responsable de numerosos problemas nacionales, que deben eliminarse. Simpatía por el fascismo y el nacionalsocialismo alemán, Barroso se extendió particularidades de la política nazi, proponiendo la eliminación de los judíos, ya que sus características malignas. El Brasil de la década de 1930, en diversos sectores, fue para la eliminación judía, según Gustavo Barroso.

Palabras clave: Gustavo Barroso, Judeu, Nazismo, fascismo, Integralismo

\section{Introdução}

Raça é um conceito oriundo de uma longa discussão ao longo da história mundial, que apenas no século XIX, com a obra de Gobineau, considerado pai do racismo científico, veio a ganhar foros de verdade. Utilizado para separar, excluir e manter a separação de grupos humanos, o conceito de raça não possui validade científica, pois as variedades fenotípicas não derivam de um único tronco racial, se assim podemos falar. Na Idade Moderna, usou-se o conceito de raça embutido na ideia de superioridade do homem branco, considerado civilizado, em contraposição aos seres bestiais do Novo Mundo para colonizá-los, levar a civilização aos trópicos. Séculos depois, sob a política de formação dos estados nacionais, a noção de raça serviu para criar a ideologia de caráter nacional, forjando identidades ao mesmo tempo que diferenças, abrindo caminho para o imperialismo.

Como a língua, o território, a força da tradição, hábitos ou crenças em comum, a ideia de raça sofreu um verdadeiro golpe e serviu para as mais incompetentes políticas destrutivas de colonização, desconsiderando tudo que não condiz com o mundo de valores do homem branco (SANTOS, 2007). Comas (1970) evidenciou que raça é um conceito que serve para legitimar situações de classe (política, social e econômica), com o objetivo de legitimar as desigualdades (BANTON, 1977). Pontualmente a partir de 1870, as elites brasileiras assimilaram nas faculdades de direito e de medicina, museus e institutos históricos, teorias consideradas científicas (determinismo, positivismo e evolucionismo), interpretando a nação, investigando seus males e propondo remédios para a solução desses. Isso causou um empobrecimento, como nos informa Dante Moreira Leite (1977), pois levava a generalizações, onde tragicamente se associava valores, comportamento moral a raça. Foi com esse escopo de leituras que a elite intelectual, política e econômica forjou os projetos de Brasil, dispensando particularidades de uma sociedade complexa, tanto do ponto de vista etnológico como etnográfico.

Isso significa que as elites brasileiras, formada por figuras fluentes no cenário político e intelectual brasileiro manipulavam conscientemente a ideia de raça para alegar que o atraso 
do Brasil se devia a uma população mestiça, biologicamente inferior, e que somente com a presença do homem branco (equivalência de raça superior, moderno, civilizado, criado em um mundo capitalista), superaria o atraso brasileiro. Assim, era recorrente em ensaios, crônicas, e sobretudo, nos romances, o tema da civilização e do progresso. O conceito de raça caiu como uma luva escondendo um passado de miséria e escravidão, a corrupção e o mandonismo das elites brasileiras. Grosso modo, raça fora o maior artificio retórico para as elites brasileiras, que em todos os momentos de crise política faziam de um problema que interessava a poucos, um problema nacional (OLIVEIRA,1990)

Nesse texto, iremos analisar como as leituras sociais brasileiras, suas interpretações e escrita na década 1930, no Brasil, não se desvinculou do padrão racista à época da geração os escritores racistas, predominante a partir de 1870, que tinham como parâmetro o naturalismo, interpretando o Brasil a par dessa visão de mundo. Não vamos encontrar obviamente a alusão a hierarquia racial, a diferença inata de seres humanas na certeza da superioridade do branco, mas sim a cristalização da ideia de 'caráter nacional', onde cada raça carregava uma série de atributos, e no caso do judeu, se mostrava com tendência a anarquia, a tomada de poder, a se preocupar apenas com o lucro, e acima de tudo, não se misturava.

\section{Caça ao judeu: projeto nacional brasileiro sem a participação deste}

Gustavo Barroso nasceu em Fortaleza em 1888, era filho do coronel Felino Barroso, tabelião e de Ana Guilhermina Dodt Barroso, que viera com o pai a serviço de obras públicas no Brasil. Seu avô era engenheiro e doutor em Filosofia pela Universidade de Viena, um típico representante da nobreza Walsore. Sua atividade literária e jornalística começa com a fundação do $\mathrm{O}$ Garoto, $\mathrm{O}$ Equador e $\mathrm{O}$ regenerador, ora participando de outros órgãos como $\mathrm{O}$ Unitário, O Colibri, O Figança e O Demolidor, este último veículo socialista de Joaquim Pimenta, ora participando de grupos literários como o Grêmio Literário 25 de Março. Participou de outras atividades culturais, sendo secretário da Talma Cearense, da sociedade literária Clube Máximo Gorki, primeira agremiação socialista do Ceará. Foi colaborador da imprensa carioca nos jornais O Malho, O Tico-Tico e a Careta, com o pseudônimo de João do Norte. Em 1911 chega ao Rio e logo se torna amigo de Coelho Neto, importante escritor das rodas literárias da Capital Federal e da Academia Brasileira de Letras. Em 1912, dedica seu livro Terra do sol: natureza e costumes do Ceará, a Coelho Neto, tornando escritor respeitado no cenário literário brasileiro (MENEZES, 2006) 
Barroso foi secretário da Comissão de Estudos do Prolongamento da Estrada de Ferro Central do Brasil de Congonhas e de Belo Horizonte, correspondente do Correio Paulistano. Em 1913 foi designado Secretário Geral da Superintendência da Defesa da Borracha, tornando-se nesse momento redator do Jornal do Comércio, até 1919. Posteriormente em 1920, foi chefe de Revisão dos Debates do Senado Federal e tradutor da prestigiada Livraria Garnier, retorna à Fortaleza para ser Secretário do Interior e da Justiça e assumir a redação do Diário do Estado, quando este era administrado pelo primo General Barroso, eleito presidente do Estado. Em 1915 se afasta de suas atividades para se candidatar ao cargo de deputado federal no Ceará, pelo Partido Republicano Conservador, apoiado pelo governo estadual e pelo maior opositor da política aciolina, que é Pinheiro Machado. (MENEZES, 2006)

Militante integralista, chefe de milícias da AIB, Barroso sempre negou ser um escritor racista, afirmava que "sua visão antissemita se elevaria mais alto do que a visão racista do nazismo alemão", ainda que saibamos de sua admiração pelos regimes totalitários e sua paixão pelas forças armadas, com a simpatia de uma nação moldada sob o modelo de um Estado forte. Em sua produção intelectual, o escritor cearense dizia que seu antissemitismo era moral ou religioso, mas um olhar mais detido nos capacita a identificar Barroso como um autor extremamente racista, com um projeto de eliminação da raça judia, que considerada vírus, bactéria ou carrapato. Seus livros estão recheados de perseguição a figura do judeu, discurso assumido por setores tanto da alta cúpula do estado, como de setores médios, temerosos com a modernização da estrutura política do país. (CRUZ, 2004)

No Brasil, figuras da Igreja como Pe. Cabral e Alceu Amoroso Lima, Olbiano Melo, Tenório de Albuquerque (os dois últimos influenciados por Barroso), endossam a imagem negativa sobre o judeu (CARNEIRO, 1995). O ataque de Barroso é fortíssimo, sua linguagem e sua concepção são sintomáticas de um homem antidemocrático, hostil à "anarquia do número", convicto na diferença natural dos homens, fundamento social e político de seu projeto integralista, regido sob o 'princípio de autoridade'. Barroso reproduziu alguns escritores racistas legitimados pelas elites católicas no Brasil e na América do Sul (CARNEIRO, 2007), reforçando um imaginário perverso que tinha o judeu como responsável pela morte de Cristo, pela profanação de hóstias, pelo envenenamento dos poços, figura capaz de destruir toda e qualquer sociedade (POLIAKOV, 1985). Uma das justificativas de Barroso para sua condenação ao judeu era, sobretudo, afirmar que este destruía os grandes impérios católicos.

Em defesa da 'Revolução Espiritual', formada pelo sentimento, alteridade e afeto, conclamando todos os brasileiros, Barroso responsabilizava o judeu pela crise do Brasil e do 
mundo, que há séculos vinha se arrastando na história. Somente a força do integralismo seria possível formar um novo Brasil, com uma nova forma de sentir, unindo os brasileiros em prol de um Brasil com Estado forte, expurgado dos males do passado. O liberalismo era conforme anotava Barroso criação judaica, este era o maior inimigo do integralismo. O homem havia perdido a relação consigo mesmo, havia se mecanizado, tornado mera mercadoria, devido a mercantilização de tudo, toda essa situação era causada porque o responsável pelo agenciamento do liberalismo, econômico e político, era o judeu.

$\mathrm{O}$ ataque de Barroso se torna ainda mais forte quando afirma que o marxismo é uma filosofia materialista, originado da filosofia pré-socrática de pensadores da Grécia. Para embasar sua ideologia espiritualista (integralista), Barroso trata de desmerecer a filosofia de Marx, considerando-a uma filosofia burguesa, a serviço das elites capitalistas. Os seguidores de Marx chegam a desfilar na obra de Barroso como prova da identificação do mal, algo satânico, colocando em cheque as sociedades. Com uma postura abertamente racista com relação ao judeu (posicionamento nosso), Barroso ver o judeu como malevolente, transgressor de toda norma social, corrosivo, subversivo, elemento que o Estado brasileiro em nenhum momento pode perder de vista.

Antidemocrata, leitor de Aristóteles, que defendia doutrinas orgânicas, e de Platão, para quem existia pessoas que pensavam, dando as cartas intelectuais e políticas, como pessoas que exerciam a vigilância do território, Barroso defende a "anarquia do número". Barroso ojeriza à democracia, o sufrágio universal, por acreditar que a democracia liberal é uma farsa, que não representa os anseios do povo, impossibilitando a real liberdade. Seu modelo de Estado está ancorado em Aristóteles (onde tudo está envolto numa estrutura totalizante, onde cada elemento faz parte desse, sem choques), reabilitado por Tomás de Aquino. Conforme Barroso, o judeu sempre esteve presente na história, marcando negativamente o cenário mundial. Para o integralista, todo e qualquer movimento perpetrado pelo judeu dissolve, corrói e desintegra, porque este desintegra as bases de uma sociedade cristã, "as doutrinas dos judeus são na verdade de traição nacional e de decomposição social, destinando-se a destruir a religião, o princípio de autoridade e ideia de pátria, transformandose em espírito odioso de classe" (BARROSO, 1934, p. 27).

Barroso alertava veementemente para a infiltração judaica no Brasil, por corroborar com o plano de uma conspiração judaica. Todos os vícios só são prejudiciais porque são orquestrados por judeus. Em sua obra é recorrente a caça ao judeu, seja remetendo a escritores maçons de ascendência judaica, seja fazendo uma leitura extremamente racista, como essa: "Bordeau reconhece as estreitas afinidades que ligam o socialismo aos traços distintivos da 
raça judaica”. Poncis, Ford, Bernard Lazare, Levi, Sáa, dentre outros, são autores sempre citados por Barroso na edificação de seu antissemitismo. Para combater o mal, só o integralismo, um Estado forte (totalitário e não autoritário ), salvaria o Brasil. Recorrendo a escritores como René Guenon, L. Fry, W. Cruetz, Roger Lamberlin, Barroso cada vez mais consolida sua imagem negativa sobre o judeu, uma vez que "mal suspeitam os povos, que trabalham e se alimentam com o suor do seu rosto que uma nação parasitária se infiltra nas glândulas do organismo social das quais dirige e comanda as funções do corpo" (BARROSO, 1937, p. 19) O imaginário judaico de Barroso, era típico de setores conservadores da elite brasileira, que assimilaram e construíram o nocivo imaginário medieval racista acerca do judeu (MOTTA, 2002)

Não há uma só obra de Barroso em que o autor não avente fatos e mais fatos da presença nefasta do judeu. O judaísmo tinha escravizado o mundo, tinha se mostrado ilusório na solução do caos mundial, só havia aumentado a miséria do trabalhador, acentuando a Questão Social. O judeu incitava a guerra entre as classes para delas tirar proveito, essa era apenas uma das características da baba judaica, dos adoradores do capital, do bezerro de ouro, do Kahal, do sinédrio, da acácia, enfim, do Judaísmo Internacional.

Há momentos em que Barroso trata o judeu como raça, atribuindo inclinações a este, como um sujeito dado a pecúnia, sem amor à pátria, adorador do capital, dando a entender que o judeu não media esforços para se embrenhar no mundo do capital. Ainda que o judeu tratado por Barroso e pela elite brasileira seja um judeu imaginário, pensado pelas elites europeias como afirma Lesser (1995), o que nos interessa é a postura ideológica (racista) do integralista. Outra questão extremamente importante é identificar a partir de qual ou de quais elementos Barroso 'montava' sua concepção sobre o judeu: era a partir da raça, de um grupo, de uma classe, de uma religião?

Todos esses elementos formam o imaginário sobre o judeu pensado por Barroso, advindo daí atributos que se ligam a raça, conferindo, para alguns intérpretes de Barroso, um escritor destituído de racismo, o que é uma inverdade. A força mundial do judeu é uma constante em sua obra, sendo este considerado parasita, verme, bacilo, carrapato, uma verdadeira camarilha de ladrões. Para Barroso o judeu faz de tudo para tirar proveito, é egoísta, não possui amor a sua pátria, daí a verdadeira campanha antijudaica movida pelo escritor cearense, por ele considerado o 'inimigo número 1' do país. Barroso desenvolve suas análises partindo da ideia de um judeu como raça, atribuindo características aos 'filhos de Israel', sustentando assim seu antissemitismo moral e religioso. Barroso é um antissemita clássico que acredita no mito da conspiração, mas "não há, portanto, nenhuma base em que se 
possa fundamentar o clamor dos que defendem a teoria de uma raça judaica; é um mito biológico que não possui bases válidas para justificar uma atitude antissemítica" (COMAS, 1970, p. 38).

Barroso fala do judeu bem estabelecido socialmente, de um grupo de pessoas que embora participem de movimentos de esquerda são analisados sobre a generalidade do judeu bolchevista (de caráter anárquico que contempla algumas particularidades que já mencionamos), concebido como comunista, disposto a expandir a ideologia moscovita para o mundo. Bem situado socialmente, temeroso pelas mudanças do quadro social que estaria por vir, o pensamento reacionário de Barroso, como dos demais integralistas (o integralismo nada mais é que um movimento 'político' rigidamente ordenado de fundamentação cristã), é um pensamento totalitário que combate a manifestação viabilizada pelos meios de participação democrática, pois existem os escolhidos para forjarem as diretrizes políticas, que são os intelectuais católicos, na concepção de Barroso. Barroso é um antidemocrata por excelência, as ideologias esquerdistas são fortemente condenadas pelo escritor a favor de um Estado forte.

\section{Nacionalismo eliminacionista}

O escritor cearense no capítulo sobre O Nosso Antissemitismo, do livro Judaísmo, Maçonaria e Comunismo, de 1937, afirmava que o racismo germânico não era um movimento reacionário ou despropositado como pensavam os ignorantes, era um racismo instintivo a uma raça que queria dominar o mundo por meio do capitalismo e do comunismo. Essa é uma das poucas passagens na vasta produção integralista de Barroso onde vamos encontrar de forma direta seu posicionamento acerca de sua visão racista a figura do judeu. Segundo ele, o judeu é que era um povo racista, que não se misturava. Um primeiro olhar não nos autoriza a conceber Barroso como racista, pois o escritor não associa abertamente os males do liberalismo, do marxismo, da maçonaria, e tantas outras 'manifestações judaicas' a raça desses povos de origem semita. Mas, quando realizamos uma leitura mais apurada de tais 'manifestações judaicas' logo notamos que o escritor associa ao judeu caracteres como pecúnia, parasitismo, anarquismo. O judeu era acostumado de modo "diabólico, infernal, digno de indivíduos de predisposição especial para a traição e para a destruição sistemática" (BARROSO, 1937, p. 153). É dessa força ou potência econômica que surge a ira de antissemitas como Barroso: a justificativa incide sobre algo sem sustentação tanto do ponto de 
vista histórico como científico, especificamente, biológico. Eliyahu Bilelzky sintetiza a série de acontecimentos atribuídos ao judeu,

\begin{abstract}
Não haveria laudas de papel suficientes para descrever o emaranhado de mentiras, calúnias e epítetos rotulados sobre o judeu desprezado, como pretexto de derramar seu sangue. "Os judeus são hereges em um país cristão"; "os judeus são estrangeiros em um país de nacionais": era castigado por ser rico e por ser pobre; por constituir um elemento social indesejável, concorrente perigoso ou explorador; parasita ou mendigo miserável. Acusavam-no, de um lado, de ter ideias radicais e revolucionárias, e, de outro, de incorrigível conservadorismo. Na Idade Média, o símbolo da diferenciação do judeu, que devia ser extirpado, era a religião. Em seu nome, se acendiam fogueiras para queimar os judeus e sua criação espiritual. Posteriormente, foi a alma "contaminada" do judeu, e, mais tarde, até nossos dias, o nacionalismo, isto é, sua insistência em querer viver como nação em sua terra. Essa pretensão peregrina tem agora o nome de "racismo". Houve uma época em que o judeu foi considerado cosmopolita e antinacionalista. Para uns, o judeu era um homem rígido, com o qual era difícil negociar, pela falta de flexibilidade; para outros, era indigno da confiança do próximo, por ser impiedoso, enganador e usurário. Fanático religioso e, ao mesmo tempo, herege, e, por ambas as causas, destinado à fogueira. De um lado, um epicurista decadente e, de outro, obscurantista aferrado a ideias obsoletas (BILETZKY, 1982, p. 50).
\end{abstract}

Barroso afirma que seu antissemitismo é 'moral' ou 'religioso', mas nunca racial, em um país sem ódio de raças, formado sob a harmonia de todas as raças. Analisando seus livros vemos o autor destilar um ódio sem precedentes à figura do judeu, uma linguagem semelhante à utilizada pela política nazista do III Reich. Lembremos que inúmeros são os autores citados por Barroso (Levi, Poncis, Sáa, Lazaré), onde na maioria das vezes não se ver uma posição definida por parte do autor, pouca são as situações onde se percebe uma posição racista, mas em certos momentos de sua obra, baseadas nos autores racistas citados presenciamos palavras como esta, "antes da completa eliminação do elemento judaico - declara Teodoro Fritsch - os povos não se curarão de suas enfermidades". As agressões do integralista permeiam toda a sua obra e momentos há em que seu posicionamento se transforma em ódio, tanto ódio que o próprio Barroso se justificava frente o injustificável, "não é por ódio, desdém ou desprezo que se deve fazer uma campanha sistemática contra a judiaria infiltrada por toda a parte e sim por instinto de conservação. O qual nos obriga a querer viver livres dum povo carrapato ou piolho, duma raça parasitária, como qualquer pessoa quer viver sem pulgas e sem bichos de pé...” (BARROSO, 1937, p. 75).

Diversas pesquisas negam o caráter racista do escritor, vários integralistas (alguns seguidores de seu pensamento), combatem acontecimentos atribuídos ao judeu, mas não fogem a visão pejorativa semelhante à de Barroso, que corroboram com a crença malévola da figura do judeu, portadoras de particularidades raciais. É que como escreve Goldhagen o 
antissemita não carece de bases reais para a realização de seu ódio. Boa parte dos trabalhos focaliza o antissemitismo de Barroso recorrendo a algumas de suas representações, como o Capitalismo Internacional, Socialismo, Comunismo, Maçonaria, etc, sem a elaboração de uma análise minuciosa da visão racista do escritor.

Descrente com um projeto de Brasil nos moldes do liberalismo conservador brasileiro, Barroso escoava seu brado nacionalista de salvar o país da peçonha judaica, que impedia a formação do novo Brasil. O judeu colocava em risco o projeto integralista de Barroso, que aderia a uma ideologia política atenuadora de conflitos, que era o modelo de Brasil integral, de um Estado forte. Nada soa tão claro nos argumentos de Barroso sobre o judeu do que o parasitar, o enriquecer sem o menor esforço à custa do outro, a vontade desmedida de lucrar de uma figura sem amor à pátria, indo fazer a revolução na terra dos outros. Escrevia Barroso que o judeu se infiltrava, não criava nada de positivo, era incapaz de formar qualquer organização social, enfim "racialmente, o judeu não possui o menor sentimento nacionalista, do que decorre sua grande capacidade de fingida adaptação. O diabo é o seu fedor judaico, que o não larga e faz com que os conhecedores de judeus, os indenkenner, como dizem os alemães, os sintam e reconheçam a distância. Não se ocidentalizam nunca...” (BARROSO, 1937, p. 84)

A concepção de 'agente infeccioso' por parte do judeu era algo inconteste, uma vez que "essa raça invade os organismos sociais disfarçadamente e os corrói, conseguindo conservar-se no meio da podridão que provoca para ir vencendo. É como o demônio: vence poluindo. Invade o sangue, invade a riqueza, invade o Estado, invade a própria religião, invade a vida mental!" (BARROSO, 1937, p. 84-85). O judeu era uma raça de parasitas sociais, eram verdadeiros glóbulos que infestavam todo o órgão social. No Rio de Janeiro, Barroso comentava a ação diabólica do comunismo sob a figura do líder Henri Berg, em 1935, concebendo o movimento político comunista da pior maneira possível, "naturalmente a coceira aumenta. Já muita gente a estar sentindo. E chegará o dia da aplicação dos inseticidas necessários, de dar na nação o mergulho salvador no banheiro carrapaticida" (BARROSO, 1937, p. 148). Barroso fala em 'infecção', 'micróbio judaico', 'furunculose', alude à pulga, piolhos e carrapatos numa clara alusão de seres que sugavam a economia e exploravam o trabalho do outro, considerando o judeu como 'bando de criminosos', 'tramoia de lama e sangue', 'verdadeiros bandidos sem pátria'.

A nosso ver é justamente pelo discurso da possibilidade da inserção do judeu na cultura brasileira, que Barroso mostra a ponta do iceberg de sua intolerância racista, pois seus livros apontam para um judeu racista, sem a menor capacidade de viver em outra cultura que 
não a sua. Se o Brasil era um país sem conflitos raciais, um país que nunca experimentou ódio entre as raças, porque num momento específico da história brasileira a figura do judeu é concebida como 'agente infeccioso'? O Estado brasileiro foi formado pelo poder do dono de terra e da 'superioridade' do homem branco, de mente autoritária, conservadora e racista, que sempre excluiu boa parte da população.

Falando de maneira objetiva, foi da frágil 'identidade nacional' brasileira (uma nação formada pela mistura racial e cultural das três raças), que paradoxalmente fez da sociedade brasileira uma sociedade racista. A frágil hierarquia social do Estado nacional que fez do público um espaço predominante privado, ao mesmo tempo em que elegeu o português como superior, considerando negros e índios como inferiores, permitiu que todas as 'raças' pudessem alcançar o mesmo prestígio; mas sabemos que o racismo no Brasil assim como em outros países foi um importante instrumento político, instrumentalizado nos momentos de crise política e econômica. Da frágil formação nacional é que surge justamente a busca pela identidade do país, onde se nega o passado do país jogando para o futuro a solução de seus problemas.

Uma vez que jamais houve no Brasil pano de fundo histórico para o surgimento de correntes radicais xenófobas, o inimigo da 'cultura brasileira', diferentemente da Espanha, estava em seu próprio interior, era aqui mesmo que morava os principiais inimigos da nação. Nada parece ser tão ambíguo: o ponto de partida de nossa identidade cultural é justamente o ponto a ser esquecido, o que explica um país onde a cultura judaica se desenvolveu, apesar do policiamento do Estado Novo (CYTRYNOWICZ, 1992). Com inúmeros problemas jogava-se para o futuro a solução desses, às vezes num movimento contrário, que chega ao 'paraíso', às vezes sendo vista de maneira 'camarada'. É a maneira 'leve' de encarar a vida, é o 'deixa a vida me levar' (SORJ, 2010). Num país sem história aos tempos de sua construção como nação, o índio figurou justamente pela negação da condição de sua existência, frente a brutalidade que lhe fora dirigida, sofrendo perseguição, dominado pelas camadas senhoriais brasileiras, 'em um território onde as raças habitavam amistosamente'. É dessa fluidez 'racial' que se origina a clássica ideia de paraíso racial, que se esconde o racismo e preconceito das elites brasileiras. Uma vez que o judeu se mostra um problema apenas na década de 1920, em decorrência da perda de espaço para grupos 'modernos', sem romper os laços com uma 'burguesia agrária', extremamente conservadora, vemos o argumento de Barroso reverberando a política dos regimes fortes.

Nação formada sob o espírito de cordialidade, mas que sempre guardou a intolerância e o preconceito em suas entranhas, foi devido a não 'oficialização' do racismo que a 
desigualdade e comportamentos extremamente racistas se fazem presente até hoje. No Brasil, a cultura africana juntou-se a elementos de um catolicismo rústico formadora do 'catolicismo oficial', misturada com ritos da cultura indígena, presentes, sobretudo no léxico e na gastronomia. Guardadas as devidas proporções essa é a leitura de Sorj, que desce as raízes da formação 'racial' brasileira, analisando a inexistência de antissemitismo no Brasil. Daí é que o autor discorda de Lesser, este por sua vez discorda da hipótese de Tucci Carneiro, sobre a diminuição do número de judeus diante da implantação das circulares secretas.

Mas, nos interstícios desse quadro social caminhava a 'ideologia do branqueamento', que mostrava sutilmente o racismo brasileiro, e tragicamente, trazia a exclusão e o extermínio das populações não brancas. Raças biologicamente inferiores eram a causa do 'atraso' do país! O progresso estaria no futuro, homens como Sílvio até apontaram o tempo para a formação de um 'Brasil branco'. A perversa ideologia do branqueamento produz o racismo porque em si mesma é uma ideia que valoriza negros e mestiços justamente por negar sua importância. Não se trata de trocadilhos tão pouco de prolixidade, mas de olharmos para o cenário onde em momentos pontuais da história do país a temática racial foi ferramenta política para salvaguardar a ordem, e trazer a 'modernidade' para o Brasil viabilizada por um 'discurso nacional'. (COSTA FILHO, 2018)

Foi por essa razão de coisas que desde o 'racismo cientifico' da Geração 1870 nossas elites selecionaram e recodificaram ideias científicas para justificar as manobras políticas, combatendo a escravidão e instaurando a ordem republicana, inaugurando uma ordem não mais atrasada, não mais ligada a uma economia agrária, mas urbana, uma inverdade, pois até os anos 1980 o neoliberalismo regurgitava os interesses de uma burguesia agrária. Se o racismo contra o judeu nos idos de 1930 não se transformou em ações concretas em nenhum momento significa reconhecer a existência da democracia no Brasil. Estar provado que o argumento racial fora utilizado num primeiro momento para mostrar que o ex-escravo recémliberto não tinha condições de lidar com uma sociedade 'moderna', com as formas civilizadas de viver; no segundo momento a perversão da raça recaiu sobre japoneses e judeus, raças com predisposição a desordem e a anarquia (AZEVEDO, 2004). O fato de que o racismo não se transformou em realidade ("fora uma transfiguração do real"), como lembra Luizetto analisando a constituição de 1934, não significa que a humilhação e o preconceito da submissão de um povo, apenas possível devido a simpatia por parte das elites políticas, econômica e letrada do Brasil dos séculos XIX e XX. No cenário da guerra assim como alguns judeus viam o Brasil como paraíso (GRUN, 2000), a alta cúpula Rio Branco se flexibilizou ante o perfil de judeus ricos, vendendo cartas de entradas, mostrando a face de um 
país que sempre mostrou seu lado mercantil, carecendo de ideias para justificar suas práticas corruptas (CARNEIRO, 1995). Por isso, as brechas na lei para a entrada de judeus, e a preocupação pontual e estratégica do estado para com os judeus do leste europeu, influenciados pelo comunismo. O problema não era a nacionalidade, mas sim um discurso de classe por parte do Estado classista, que sempre rejeitou os despossuídos.

A inexistência de um racismo aberto foi responsável, paradoxalmente pela alternativa política autoritária, xenófoba e racista no Brasil. Antes mesmo da fala oficial da eminente cúpula Rio Branco a caminho do Estado Novo, o Brasil deu lastro para a apoteótica frase do 'sabe com quem estar' falando. A discriminação e o racismo movido contra o judeu foram apenas uma mudança com relação ao elemento perseguido e não do comportamento preconceituoso e racista de nossas elites, que sempre temeram as massas e que conceberam índios, negros e mestiços, como agentes responsáveis pelo 'atraso' do país por serem raças biologicamente inferiores. (SCHAWRCZ, 1995)

A falta de um antissemitismo aberto por parte do Estado brasileiro que não perseguiu fisicamente comunidades judaicas (jamais esquecendo as bases de formação do Estado brasileiro e o posicionamento racista de Barroso para com o judeu), não deve ser associada em momento algum a falta de intolerância e de preconceito ao judeu, coroando um Brasil de democracia racial, hipostasiado por escritores clássicos do país. Sorj lembra que "não são os 'fatos' que explicam a existência ou perda de preconceito no Brasil ou em qualquer outra cultura" (SORJ, 1997, p. 27). Este fala em predisposição antissemita da sociedade brasileira, essa predisposição deve-se as tessituras da frágil formação do Brasil enquanto nação: um país de hierarquia fluida "que não permitiu cristalizar setores ressentidos e frustrados com as transformações sociais” (SORJ, 1997, p. 16). Marcos Shor seguindo o raciocínio de Sorj ressalta que "nessa perspectiva relacional, pode-se entender, além dos cálculos utilitários de Getúlio Vargas em face dos judeus em suas conexões externas, condicionantes internos relativos ao modo como segmentos da elite política pregavam máximas antissemitas" (SHOR, 1999, p. 248)

Em capítulo de livro, Shor aborda a polêmica discussão ocorrida na Academia Brasileira de Letras, ocorrida em 1992, entre Josué Montello e Arnaldo Niskir. O autor quebra com a ideia romântica (como é de costume aos deuses imortais da $\mathrm{ABL}$ ), nos chamando atenção para o caráter perverso do pensamento de Barroso. Para o escritor maranhense, Barroso era um admirador de judeus, sua face antissemita era reflexo das contingências históricas do momento, criando um 'hiato político', escondendo assim o antissemitismo do autor de Judaísmo, Maçonaria e Comunismo. Conforme o escritor: 
De qualquer forma, o artigo de Josué Montello é um excelente exercício de elucidação dos artifícios acionados pelos intelectuais (retórica, citações etc) para persuadir o adversário. Entretanto, é importante ressaltar a existência de critérios de avaliação desses instrumentos, ou seja, dos mais aos menos refinados. Neste sentido, a preocupação do acadêmico, Montello em apresentar um consenso interno para o público externo dificultou a elaboração de uma análise mais apurada das desventuras de seu amigo Gustavo Barroso (SHOR, 1996, p. 530)

O fato de não termos tido abertamente guetos ou campos de concentração, de não sermos desde o início uma sociedade que nutriu ódio ao judeu ou a outra raça não elimina em nenhum momento a fala de Barroso num momento específico e ímpar de nossa história. Sermos uma nação branca e católica, como bem lembrou Manoel Luís Salgado Guimarães (1988), com traços xenofóbicos e de intolerância, não significa um projeto por si só eliminacionista, adoçada pela velha e superada teoria da democracia racial brasileira?

O projeto eliminacionista de Barroso (CRUZ, 2004), não precisou de câmaras de gás em nome de sua eliminação, seu imaginário sobre a figura do judeu seguido de sua campanha antijudaica deixa claro o perigo de uma raça ou de um povo que o autor não cansou de falar que destruía toda e qualquer sociedade, todos os impérios católicos. Toda a obra integralista de Barroso é uma campanha de alerta contra o mal, contra a serpente, a hidra que vence todos os elementos sociais. O nacionalismo da década de 1930, somado a tradição de uma elite conservadora e xenófoba, é o pano de fundo para o racismo de Barroso, que segundo Tucci Carneiro, "com posições muito próximas da doutrina alemã, Barroso registrou suas ideias contra os judeus em suas memórias Coração de Menino (1939) e O Liceu do Ceará”, e mais: "apesar de não gostar de ser tachado de "copiador de regimes exóticos", Barroso bebeu nas mesmas fontes antissemitas que os nazifascistas, adaptando seus argumentos à realidade brasileira".

Lembremos que a AIB fora "parcialmente financiada pela embaixada alemã no Rio e, clandestinamente, pelo governo italiano", conforme assegura Lesser. Sintonizado historicamente com o racismo alemão (o integralismo tinha seu primeiro encontro três dias após a eleição de Hitler), era sintomático a ampla divulgação de uma literatura que não escapou a intolerância do primeiro movimento de massas, no caso a AIB, uma alternativa política que

refletia o nazismo, sobretudo na sua vigorosa campanha antissemita, de que se encarregava principalmente Gustavo Barroso, diretor da milícia integralista e principal intelectual do movimento. Plínio fazia praça do seu bom relacionamento com judeus (individualmente), como o industrial 
Horácio Lafer, de São Paulo, mas a imprensa do movimento atacava cada vez mais os judeus, tanto em nível nacional quanto internacional, reproduzindo frequentemente odioso material de propaganda nazista. $\mathrm{O}$ conselho nacional da AIB mantinha um serviço de informações, cuja 'seção judia' encarregava-se, entre outras coisas, da compilação de estatísticas sobre a comunidade judaica nacional e de uma lista de judeus proeminentes na vida econômica e política (LEVINE, 1980, p. 132)

Se o racismo de Barroso não se transformou em violência física contra comunidades judaicas, as instituições judaicas funcionaram normalmente no Brasil, nos referimos à violência oriunda da concepção de Barroso, tal e qual a concepção que o nazismo tinha do judeu, vírus ou parasita, carecendo ser eliminado para a criação do novo Brasil. Bem antes do alvorecer dos anos 1930, no século XVI, tempos de Inquisição, o judeu já perdera sua identidade, muitos preferiram a morte do que perderem sua identidade religiosa, como nos lembra Anita Novisnky (2007).

Estamos aqui no nível da violência psicológica, que não carece de segregação, tão pouco de campos de concentração. Barroso diversas vezes chamou atenção para o 'racismo judaico', buscando provar que não era racista, apenas combatia o racismo do judeu. Toda e qualquer dúvida se esvai quando se folheiam os livros do escritor, onde inúmeras vezes assomam o ódio motivado por questões raciais. A falta de uma política como nos moldes do nazismo, onde espaços eram divididos e a eliminação do judeu era o principal objetivo, não elimina a fala de Barroso e de seus seguidores que combatiam um verdadeiro mal, o 'cancro' que adoeceria a nação. Tucci Carneiro ao longo de seus trabalhos chama atenção para a prática de intolerância do Estado brasileiro. No caso de Barroso, a autora considera o escritor um antissemita de cunho racista.

A ideologia do branqueamento foi o principal motivo para o esquecimento do preconceito no Brasil, uma sociedade que negava seu triste passado em benefício de seu futuro glorioso. A inexistência de ressentimento por parte de nossas elites impossibilitou responsabilizar algum estrato social diante às transformações econômicas e políticas, que em tese permitia a mobilidade de todos os grupos sociais. Estas são as bases de um Brasil democraticamente racial que via seu racismo alvorecer estrategicamente pontualmente, quando os discursos nacionais operavam a busca pelas raízes brasileiras, pela identidade nacional, convergindo a tríade racial. Dessa forma não são necessariamente os fatos que nos servem de parâmetro para uma sociedade racista ou não, mas sim suas bases formadoras, conforme aponta Sorj, em uma cultura que via no estrangeiro o progresso, as novas ideias e alternativas para o país alcançar seu objetivo no futuro. Esta é a razão para o surgimento do 
imaginário negativo do judeu após a Revolução de 1917, não esquecendo a visão de um escritor do porte de Gilberto Freire para quem judeus eram 'aves de rapina', 'velhacamente matutos', 'sem escrúpulos', 'estranhos ao meio', 'usurário', etc (CARNEIRO, 2003, p. 111).

O fato de não ter existido no Brasil violência aberta ao judeu não apaga o preconceito, a discriminação e o forte racismo incrustrado num país que teve em todos os seus projetos nacionais o discurso racial. Assim como negros, índios e mestiços, o judeu desde a década de 1920 tornou-se um 'indesejável', era o maior inimigo do país, empecilho das elites urbanas comungadas com setores tradicionais de nossa sociedade. A assimilação pensada por Barroso e seus seguidores redundou num 'antissemitismo moderno' que não permitiu a identidade de grupos judaicos. Não é gratuito que Barroso nos chame atenção para a fraternidade das raças brasileiras, no Brasil sem 'guerra de raças', para a construção do Brasil integral. Mas, como nenhum outro intérprete da nossa cultura (Barroso se considerava um extremo conhecedor do folclore brasileiro), sabia do obstáculo intransponível ocasionado pela presença judaica.

A crença nos Protocolos já nos autoriza a enquadrar Barroso como um escritor racista. Concordar que houve desenvolvimento da cultura judaica durante a implantação das circulares secretas, somado ao fato de que o antissemitismo não se transformou em ações físicas (lembremos do choque entre integralistas e comunistas na Praça da Sé), não apaga a fala discriminatória e racista de um "admirador declarado de Hitler e do nazismo, o que fez com que o pró-nazista Deutsche La Plata Zeitung de Buenos Aires o chamasse de "Fuhrer do Integralismo" (LESSER, 1995, p. 112). Recorremos a Levine para citar esta passagem: “o jornal Der Sturmer, de Julius Streicher, elogiou as obras racistas de Gustavo Barroso e ele gozava de bom conceito na Alemanha" (LEVINE, 1980, p. 138). Com sua visão racista, Barroso participou de duas tentativas de derrubada do estado novista, onde chegou a consultar as embaixadas da Itália e da Alemanha visando apoio financeiro destas, foi afastado da edição do jornal A Offensiva por Plínio Salgado justamente por sua visão racial com relação ao judeu. Tucci Carneiro aponta que "os conceitos e valores antissemitas sustentados por Gustavo Barroso foram alimentados através de seus constantes contatos com a Alemanha e conhecimento aprofundado da literatura nazi-fascista”. E mais:

Intelectuais do Sigma, em vários momentos, pronunciaram conferências sobre o racismo alemão, não escondendo sua admiração pelo Reich e pelo Fuher, pela nova Itália e por Mussolini. O panorama europeu estava fértil em exemplos ditatoriais servindo de inspiração não só aos integralistas, mas a todos aqueles que atrelados ao processo de consolidação política do Brasil, buscavam modelos para uma proposta "autêntica" de projeto de construção de um Estado nacional. Os governos nazi-fascistas pareciam-lhes o ideal, 
pois as práticas ideológicas desses regimes forneciam subsídios para a elaboração de um discurso de legitimação da dominação (CARNEIRO, 1990, p. 7)

Barroso prefaciou a primeira edição dos Protocolos dos Sábios, "entre os que mais aprenderam com os Protocolos distingue-se Adolfo Hitler que deles adotou a técnica de atribuir aos judeus (e, aliás, também à franco maçonaria) a culpa de todos os males e calamidades que afligem o mundo" (ROSENFELD, 1982, p. 400). Nenhum escritor fora tão antissemita como Barroso: para ele toda a história é senão a ação das forças secretas que agem nos bastidores da História. Em A Questão Judaica, capítulo da obra O Que o Integralista deve Saber, o escritor trata de mostrar a veracidade dos Protocolos. Para além do esforço de Barroso para provar a verdade da 'fraude literária', recorrendo a W. Creuz, L. Fry, Gottfried, o integralista afirmava que seu antissemitismo era uma questão moral e religiosa, mas não racial.

Mas, o 'antissemitismo político' do escritor logo mostrava sua tonalidade racista. O caos político que viu emergiu o mundo no Segundo Conflito Mundial, tinha como principal responsável a figura do judeu, considerado por Barroso como 'um bando de criminosos'. Para conter um povo com objetivos de implantação de um ‘Estado dentro do Estado' que destruía os povos para dominá-los, só o regime nazista seria capaz de deter este grande mal, "o que Hitler pratica nos nossos dias é a repetição do que fez Tibério em Roma e, antes de Tibério e antes de Cristo, o pretor Hispalus. É a defesa do Estado. É a defesa da civilização. Damos somente os dois exemplos de Roma, afim de evitar repetições enfadonhas”. (BARROSO, 1935, p. 120)

Combatendo o "fermento desagregador das sociedades cristãs", escrevia Barroso: "afirma Creuz que a quintessência do perigo judaico é a camuflagem. Justamente, Raça e assimilação são as camuflagens com que certos judeus escondem sua ação eminentemente política no seio de qualquer sociedade, com o fito louco do domínio" (BARROSO, 1935, p. 127).

Extremo conhecedor da literatura nazifascista, admirador dos regimes de Mussolini, Hitler e Salazar, e acima de tudo, considerado a maior figura antissemita das Américas, divulgador dos Protocolos, nos autoriza a caracterizar Barroso como um escritor racista, pois o integralista assim como os nazistas fizeram desta farsa literária a bíblia para o genocídio dos judeus, responsabilizando estes pela morte de crianças para fazerem uso de seus sangues em ritos, e acima de tudo, por conceberem o judeu como agente infeccioso, indo de vírus a bactéria, que precisava ser eliminado do organismo social. Barroso como todos os 
antissemitas é extremamente convicto na autenticidade dos Protocolos (embora o integralista paradoxalmente titubeie em algumas passagens da seguinte forma 'verdade ou não'), recorrendo aos mais autorizados 'teóricos' do Nazismo, de modo a tornar inconteste a fraude de Maurice Joly. É que Barroso acredita na maldade levada aos extremos por ser um paranoico como diversos antissemitas, pois a certeza do imaginário nefasto do judeu é o que dar sentido a suas análises. Daí a recorrência de suas frases sem recorrer aos autores, elaborando livros que mais lembram panfletos, com objetivo de convencer o leitor pelo cansaço, pela repetição, como lembra Cytrynowicz.

O que norteou a produção de Barroso, sua visão e posicionamento como ideólogo na formação de seu projeto político (integralista), foi assim como o regime nazista sua campanha anti-judaica. Para o escritor cearense, o judeu com suas criações quebrou com os lineamentos sociais dos tempos harmônicos dos idos medievais, era um sujeito de sabor anárquico, com inclinações que impediam a formação do Brasil sob um Estado forte. O fato de ser judeu já é o suficiente para Barroso destilar seu ódio. A generalização à figura deste já é o suficiente para o integralista descer a uma análise minuciosa dos prejuízos causados por este povo. Bem lembra Todorov que nos regimes totalitários "o inimigo é a grande justificativa do terror; o Estado totalitário não pode viver sem inimigos. Se lhe faltam, ele os inventará. Uma vez identificados, não merecem nenhuma piedade" (TODOROV, 1999, p. 36).

Barroso perscrutava a existência judaica onde quer que seja: na numismática, nos sobrenomes familiares, nas tradições, enfim, tudo isso porque o mal é a figura do judeu, "Esse simplismo - que mais que simplicidade é falta de inteligência política - talvez explique o sucesso de seus livros, quando a sociedade estava em crise e os poucos projetos ideológicos existentes eram antes de tudo confusos. Nessa situação, a criação do 'culpado' resolvia o problema de muita gente. E, como a história ensina, não há melhor 'culpado' que o judeu". Chiavenato conclui que

Nada detém Gustavo Barroso contra os judeus: "aliás, há opiniões de que é um povo de loucos e tarados". Como prova, cita as estatísticas da polícia alemã para afirmar que $24 \%$ dos criminosos da Alemanha eram judeus, embora fossem $0,76 \%$ da população - não sabe tirar a relação disso e garante que "os judeus fornecem, sendo uma minoria ínfima, em relação à população do globo, 30\% dos criminosos do mundo!!!. (CHIAVENATO, 1985, p.266)

Em um país que para Barroso e para muitos intérpretes da cultura brasileira em nenhum momento de sua história enfrentou uma 'guerra de raças' sendo possível a assimilação (fusão) de todas as nacionalidades, torna ainda mais emblemático a postura racista de Barroso para com o judeu. Citando um sem número de autores (racistas ou não, 
homens ligados à maçonaria e até mesmo judeus), podemos ver particularidades do projeto de eliminação nazista em Gustavo Barroso, embora o escritor sempre estivesse a diferenciar seu antissemitismo do 'racismo germânico', alegava que este era uma "doutrina que se elevava mais alto", o escritor vivia uma realidade social e política que não comportaria racismo!

Essa fala naturaliza o posicionamento de Barroso tornando seu racismo legítimo porque cava aquilo que pertence ao judeu daquilo que pertence ao não judeu: é o maniqueísmo que sedimenta a visão dos antissemitas. Simpatizante de Hitler, influenciado por uma figura como Feder, Barroso salientava sua origem alemã ainda que quase nada tenha assimilado de sua familiaridade, sua formação foi laica e a cultura francesa foi de fundamental importância para sua geração. Carlos Nóbrega de Jesus analisando o revisionismo sobre o holocausto, em suas versões publicadas pela Editora Globo conclui que figuras como Plínio Salgado e Miguel Reale não eram menos racistas que Barroso, a diferença era assumir uma posição claramente racista em uma cultura católica, o que é dúbio, pois o antissemitismo foi antes de mais nada um movimento de valores cristãos.

Se o antissemitismo de Barroso fora mera tática política como chega a aventar Trindade, para rivalizar com Salgado e Reale, foi essa tática que fez de Barroso uma antissemita como todos de seu estilo, homens paranoicos que via um judeu coberto de taras, com odor, semelhante a porcos, comparados a vírus e bactérias que chegavam a coçar. $\mathrm{O}$ Brasil não era a Alemanha, por aqui não houve um 'ódio compartilhado' (GOLDHAGEN, 1996), que independente da chacina movida aos judeus trazia a essência de uma nação que por razões históricas (de identidade), transformou o judeu como o principal inimigo da nação alemã.

Se o escritor justificava seu racismo como diferente ao racismo de Gobineau, não podemos esquecer os termos utilizados pelo integralista para incriminar o judeu e assim desejar sua morte! O intento eliminacionista de Barroso deriva de sua convicção sobre o judeu, verdadeiros 'vermes', 'bactérias', 'bacilos', 'carrapatos', 'glóbulos vermelhos' que contaminavam e destruía qualquer sociedade. Somado a esta verdadeira linguagem profilática o escritor denominava o judeu como 'bando de criminosos', pessoas traiçoeiras, usurpadoras, covardes, acostumadas a tomarem o poder a partir dos pequenos golpes. Não faltavam termos agressivos em sua obra, o judeu não é capaz de criar nada grande, "só pensa em dinheiro", por não ter pátria "vai fazer a revolução na terra dos outros", criando um "Estado dentro do Estado".

Toda a obra de Barroso possui legitimidade porque é um ataque ao 'mal', uma imagem que perpassou toda a Idade Média se arrastando até a Idade Moderna, sendo 
revitalizada pelas teorias do evolucionismo e do determinismo, se transformando no racismo biológico, que serviu de instrumento para formação de algumas nações. Foi a Igreja a responsável por essa triste imagem, uma postura covarde como nos lembra Júlio José Chiavenato. A não existência de câmara de gás ou de guetos não tornam as palavras de Barroso menos agressivas ou racistas, a linguagem que usava advinha de sua plena convicção de autores racistas que inspiraram o nazismo. Carlos Nóbrega de Jesus (2006) aponta que é compreensível o posicionamento de Barroso, seria extremamente difícil admitir abertamente o ódio ao judeu em uma sociedade católica e de fraternidade 'racial'. Mas essa sociedade católica não reforçou o antissemitismo de um escritor católico como Barroso? Tamanha era o ódio ao judeu que o escritor chegava a introduzir capítulos de seus livros com rótulos, acreditando no imaginário malévolo do povo de Israel.

Nas cortes de 1841 protestavam os procuradores dos conselhos contra a ousadia de alfaiates, sapateiros e mais menestréis da grei judaica penetrarem em suas casas, a seduzirem-lhes as filhas e as mulheres"

(Mario Saá - A Invasão dos Judeus")

...exercitam a língua na mentira, e só estudam o mal que que hão de fazer"

(Jeremias, IX, 5)

Para dominarem, os judeus não receiam atraiçoar. Tem de longa data esse costume, desde José e os Faráos. Citemos alguns fatos irrecusáveis. Os godos tinham sido duma bondade sem limites para com os judeus estabelecidos na Espanha. O muçulmano Tarik conquistou-a em 711 com o auxílio dos judeus exilados que entraram no seu exército e dos judeus que permaneceram na Espanha

("Bernard Lazare - "L'anti-semitismo")

Os judeus são uma nação. Esta nação persuadiu-se de que o mundo the pertence. Não tem outro meio de chegar a seus fins senão pela corrupção dos espíritos que conduz á decomposição da sociedade".

(Marquês de La Tour du Pin)

Israel deve desnacionalizar todos os povos".

(Opinião do judeu Ricardo Bloch).

A nossa Pátria deve tornar-se a Humanidade".

(Naguet - "L'humanité et La patrie").

Pátria é a igualdade de direitos e deveres".

(Definição do judeu Crémieux)

Enquanto os judeus tem a missão de arruinar o ocidente, os muçulmanos deverão arruinar os Impérios coloniais inglês e francês".

(Bolchevisme de Salon, pg.476).

O judeu é anti-germânico por ser individualista e universalista, detestando as sociedades militares".

("L. Woff - "Jewish Ideals and the war").

De todos os tempos tem sido o fim dos judeus uma luta de morte, imperdoável, inexpiável, contra o cristianismo saído deles próprios. Seu sistema constante tinha sido o racionalismo, o criticismo a outrance, depois o anti-clericalismo penetrante. Constituíram sucessivamente a gnose, a cabala, a exegese; foram verdadeiramente os doutores da incredulidade".

("Bolchevisme de Salon", pg.553)

Nos judeus, o cérebro escoou-se para os órgãos genitais do intelecto". 
(K. Elschmid - "Art Libre")

A sodomia ou o homossexualismo era um hábito atribuído ao judeu e nisso se celebrizaram Sodoma e Gomorra. Os antigos portugueses, e mesmo nos séculos XVII e XVIII assacavam aos hebreus as mesmas tendências... O panfletista Vicente da Costa Matos assevera, em 1625, que os judeus eram homossexuais, e que tinham introduzido o vício no país..."

(M. Sáa - "A invasão dos judeus")

Barroso realizou uma verdadeira campanha contra o perigo judaico, dada sua periculosidade e inclinações. Como se não bastasse, o judeu estava por trás de redes de espionagem, de redes terroristas, de prostituição, como também estava envolvido no comércio de armas e de drogas.

\section{Considerações Finais}

Destacado escritor e militante integralista, Gustavo Barroso foi chefe dos camisas verdes do movimento político e intelectual, criado por Plínio Salgado, em 1932. Com uma obra do começo ao fim de perseguição a figura do judeu, Barroso pensou o Brasil pós-1930 sem a presença do que considerava 'raça indesejável', com inclinações que iam do assalto ao poder até a sede de ganhar dinheiro, 'passando por cima de tudo'. Revivendo mais uma crise econômica e política, no qual o marxismo era uma verdade, Barroso foi simpático a ideologia dos Estados fortes, que pensa uma democracia de 'cima para baixo', tendo como característica o combate a 'anarquia do número', a hierarquia social de uma sociedade estratificada e a formulação das diretrizes políticas por parte de intelectuais (laicos ou religiosos), que são os eleitos, os capacitados na formulação da sociedade que traga a 'verdadeira democracia'.

Combatendo a democracia liberal, Barroso responsabilizava o judeu como criador desta, sujeito sem amor a sua pátria, usurpador, racista, que ia 'fazer a revolução na terra dos outros'. Nessa perspectiva, em um momento de construção-formulação de uma política que trouxesse a estabilidade de um país tão arraigado a práticas políticas bem conhecidas de nossa história, como o coronelismo e o poder de barganha de nossas elites rurais, o integralista em seu 'projeto nacional' exclui o judeu por acreditar que este não se assimila, é formador de quistos raciais, desenvolvendo em sua produção integralista uma verdadeira campanha antijudaica. Utilizando termos de profilaxia social, o judeu deve ser eliminado, pois chega a coçar, não cria nada de positivo, sendo urgente sua eliminação para que o Brasil se forme como nação. Afirmando que seu antissemitismo era moral ou religioso, o que se ver na 
produção integralista de Barroso é a perseguição e um projeto de eliminação à figura do judeu, influenciado por autores racistas que inspiraram o nazismo.

\section{Fontes}

BARROSO, Gustavo. A sinagoga paulista. Rio de Janeiro: Editora ABC, 1937. Integralismo de norte a sul. Rio de Janeiro: Civilização Brasileira, 1937. Integralismo e Catolicismo. Rio de Janeiro: Editora ABC, 1937. Judaísmo, maçonaria e comunismo. Rio de Janeiro: Civilização Brasileira, 1937. O que o integralista deve saber. Rio de Janeiro: Civilização Brasileira, 1935. Palavra e o pensamento integralista. Rio de Janeiro: Civilização Brasileira, 1935.

\section{Referências bibliográficas}

AZEVEDO, Célia Maria Marinho. Onda negra medo branco: o negro no imaginário das elites século XIX. $3^{\circ}$. Ed: São Paulo: Annablume, 2004.

BANTON, Michel. A ideia de raça. Lisboa, Edições 70, 1977.

BILETZKY, Eliyahu. Anti-sionismo, nova face do antissemitismo. Tradução do espanhol Keila Litvak. São Paulo: Ed. B'nai B'rith, 1982.

CARNEIRO, Maria Luiza Tucci. O antissemitismo na Era Vargas (1930-1945). $3^{\circ}$ Ed. São Paulo: Perspectiva, 1995.

O Veneno da serpente: reflexões sobre o Antissemitismo no Brasil. Perspectiva, 2003. CHIAVENATO, J.J. $O$ inimigo eleito: os judeus, poder e antissemitismo. Porto Alegre: Mercado Aberto, 1985.

COMAS, J. Raça e Ciência I. São Paulo: Perspectiva, 1970.

COSTA FILHO, Cícero João. Forças do mal: os prejuízos 'raciais' da figura do judeu na produção integralista de Gustavo Barroso (1933-1937). São Paulo: Todas as Musas, 2019.

CRUZ, N.R. O integralismo e a questão racial. A intolerância como conflito. Tese (Doutorado em História) - Universidade Federal Fluminense, Niterói, 2004.

CYTRYNOWICZ, Roney. Integralismo e antissemitismo nos textos de Gustavo Barroso na década de 30. Dissertação de Mestrado. São Paulo: FFLCH, 1992.

GOLDHAGEN, Daniel Jonah. Os Carrascos Voluntários de Hitler: O Povo Alemão e o Holocausto. São Paulo: Companhia das letras, 1997.

GRÜN, Roberto. Construindo um lugar ao sol: os Judeus no Brasil. (Org). FAUSTO, Boris. In: Fazer a América. São Paulo: Edusp, 2000.

GUIMARÃES, Manoel Luís Salgado. Nação e civilização nos trópicos: O IHGB e o projeto de uma história nacional. Estudos Históricos. Rio de Janeiro, n. 01, 1988.

JESUS, Carlos Gustavo Nóbrega. Antissemitismo e nacionalismo, negacionismo e memória: revisão e as estratégias da intolerância, 1987-2003. São Paulo: UNESP, 2006.

LEITE, Dante Moreira. O caráter nacional brasileiro: história de uma ideologia. São Paulo: Pioneira, 1976.

LESSER, Jeffrey. O Brasil e a questão judaica: imigração, diplomacia e preconceito. Rio de Janeiro: Imago, 1995.

LEVINE, Robert. O regime Vargas: anos críticos (1934-1938). Rio de Janeiro: Nova Fronteira, 1980. 
LUIZETTO, Flávio V. Os constituintes em face da imigração: estudo sobre o preconceito e a discriminação racial e étnica na constituição de 1934. Dissertação de mestrado, FFLCH, USP, 1975.

MAIO, Marcos Chor. Nem Rotschild nem Trotsky: o pensamento antissemita de Gustavo Barroso. Rio de Janeiro: Imago, 1992.

MENEZES, Eduardo Diathay Bezerra de. Gustavo Barroso: um cearense ariano. Fortaleza: Museu do Ceará, 2006.

MOTTA, Rodrigo Patto Sá. Em Guarda contra o "Perigo Vermelho": o anticomunismo no Brasil (1917-1964). Op. Cit. 2002.

NOVINSKY, A. Cristãos Novos na Bahia: A Inquisição no Brasil. São Paulo: Perspectiva, 1992. OLIVEIRA, Lucia Lippi. A Questão Nacional na Primeira República. São Paulo: Brasiliense, 1990.

POLIAKOV, Léon. A Europa Suicida: 1870-1933. História do Antissemitismo IV. São Paulo: Perspectiva, 1985.

RIBEIRO, Ivair Augusto. O Antissemitismo no Discurso Integralista no Sertão de São Paulo: os Discípulos de Barroso. (Org). CARNEIRO, Maria Luiza Tucci. In: O antissemitismo nas Américas: memória e história. São Paulo: Edusp, 2007.

ROSENFELD, Anatol. Mistificações Literárias "Os Protocolos dos Sábios de Sião”. São Paulo: Perspectiva, 1982.

SANTOS, Boaventura dos Santos. Para além do pensamento abissal. Das linhas globais a uma economia de saberes. Novos Estudos, CEBRAP, nº 79, novembro, 2007.

SHOR, Marcos. Marcas de uma trajetória: a Militância Antissemita de Gustavo Barroso. (Org). NOVINSKY, Anita. In: Ibéria judaica: roteiros da memória. Rio de Janeiro-São Paulo: Expressão e cultura, Edusp, 1996.

SORLIN, P. O Antissemitismo Alemão. São Paulo: Perspectiva, 1974.

SCHWARCZ, Lilia Moritz. Complexo de Zé Carioca: notas sobre uma identidade mestiça e malandra. Revista Brasileira de Ciências Sociais, São Paulo, Anpocs, p. 49-63, 1995.

TODOROV, Tzvetan. O homem desenraizado. Rio de Janeiro: Record, 1999. 